\title{
Seed yield and subsequent emergence pattern of subterranean clover cultivars in response to summer rain
}

\author{
C.S.P. TEIXEIRA, R.J. LUCAS and D.J. MOOT \\ Field Research Centre, Faculty of Agriculture \& Life Sciences, P.O. Box 8508, Lincoln 7647, New Zealand \\ Carmen.Teixeira@lincolnuni.ac.nz
}

\begin{abstract}
At Lincoln University, Canterbury, seven subterranean cultivars rated in Australia as having different levels of 'hardseedeness' were established. Monocultures were sown in autumn and allowed to grow and set seed. Seed yields ranged from 340 to $1050 \mathrm{~kg} / \mathrm{ha}$. Heavy rain in early January 2016 resulted in a "false strike" of $\leq 4.0 \%$ of seeds during the subsequent dry February. A second emergence event in March also resulted in a "false strike" with a further 7 to $15 \%$ of total seeds lost. However, cultivars established $>1000$ seedlings $/ \mathrm{m}^{2}$ after early winter rain, which is considered adequate for future persistence. Emergence was consistent with Australian hardseededness rankings. Cultivars with hardseed ranks $<4$ may be more suitable for dryland systems in New Zealand due to their early emergence and the ability to exploit the late summer and autumn rains.
\end{abstract}

Keywords: Trifolium subterraneum, dryland, reseeding, 'Antas', 'Coolamon', 'Denmark', 'Mount Barker', 'Narrikup', 'Rosabrook', 'Woogenellup'

\section{Introduction}

Subterranean clover (Trifolium subterraneum) is an winter annual that has been promoted as a dryland pasture legume to provide late winter-early spring feed before perennial white clover and lucerne increase their growth in spring (Brown et al. 2006). Subterranean clover is the most widely sown annual clover in New Zealand pastoral systems (Monk et al. 2016). However, the commercial cultivars available are imported from Australia and local information is required to estimate initial seed yield which contributes to its persistence in New Zealand dryland areas. Subterranean clover is named for its unique ability to bury its seed, which is an advantage for close grazing systems (Norman et al. 2006). An important seed yield component is seed size which differs among cultivars. For pure swards of subterranean clover a mean of $260 \mathrm{~kg}$ of seeds/ha has been suggested as the minimum initial seed yield required to ensure an effective (1000 plants $\left./ \mathrm{m}^{2}\right)$ reestablishment (Smetham 2003). For an inland New South Wales Australian climate, Dear et al. (1993) proposed $700 \mathrm{~kg} / \mathrm{ha}$ seed set was required to guarantee a legume dominant pasture. This is because autumn establishment is prone to "false strike" whereby seedlings that emerge from early rainfall events fail to establish due to subsequent dry spells (Dodd et al. 1995).

Persistence of subterranean clover is also affected by the degree of hardseededness (due to an impermeable seed coat), which differs among cultivars and across environments (Hudson et al. 2015). The Australian hardseededness rating system (0-10 scale) (Nichols et al. 2013) does not always reflect field emergence because it is affected by management, agronomic (Taylor 2005) and physiological traits (Nicotra et al. 2010). Dear et al. (1993) found that for 'Woogenellup' and 'Mount Barker' approximately $60 \pm 10 \%$ of seeds produced emerged in the subsequent autumn. The remaining $40 \%$ provided the seed resource for future years. The seed bank can be added to if management allows further seed set in later years. This paper presents the initial seed yield and a quantitative analysis of the impact of "false strikes" on the seed bank and seedling losses of seven mid-late season flowering cultivars (Nichols et al. 2013) including 'Mount Barker', which is an older cultivar resident in many New Zealand dryland pastures.

\section{Methods}

Seven cultivars of subterranean clover were sown at the Field Research Centre, Lincoln University (433' $57^{\prime \prime}$ S, $172^{\circ} 28^{\prime} 04^{\prime \prime} \mathrm{E}, 11 \mathrm{~m}$ a.s.1.) on 16 th April 2015, in a randomised block design with four replicates. The commercial seeds were purchased from local suppliers and their characteristics are summarised by Nichols et al. (2013). Initial individual seed weights, estimated from four replicates of 200 seeds were: 'Antas' (spp. brachycalycinum, $11.0 \mathrm{mg}$ ), and the ssp. subterraneum 'Coolamon' (6.0 mg), 'Denmark' (7.0 $\mathrm{mg}$ ), 'Mount Barker' (9.0 mg), 'Narrikup' (9.0 mg), 'Rosabrook' (8.0 mg) and 'Woogenellup' (10.0 mg). The soil at the research site was a Wakanui silt loam (Aquic Haplustept, USDA Soil Taxonomy), classified as a Mottled Immature Pallic soil in the New Zealand Soil Classification with available water holding capacity of $\sim 150 \mathrm{~mm} / \mathrm{m}$ (Hewitt 2010). Olsen phosphorus level was $13 \mathrm{mg} / \mathrm{L}$ and $\mathrm{pH}\left(\mathrm{H}_{2} \mathrm{O}\right)$ was 5.4 . The area was cultivated with a rotary hoe to create a fine seedbed before bare, non-inoculated seeds were broadcast by hand and raked into $4 \mathrm{~m}^{2}$ plots. Sowing rates were 20 $\mathrm{g}$ of seeds $/ \mathrm{m}^{2}$ (or $20 \mathrm{~kg} / \mathrm{ha}$ ). Sufficient rain $(\sim 44 \mathrm{~mm}$ ) for germination occurred on 28th April (Figure 1). The 


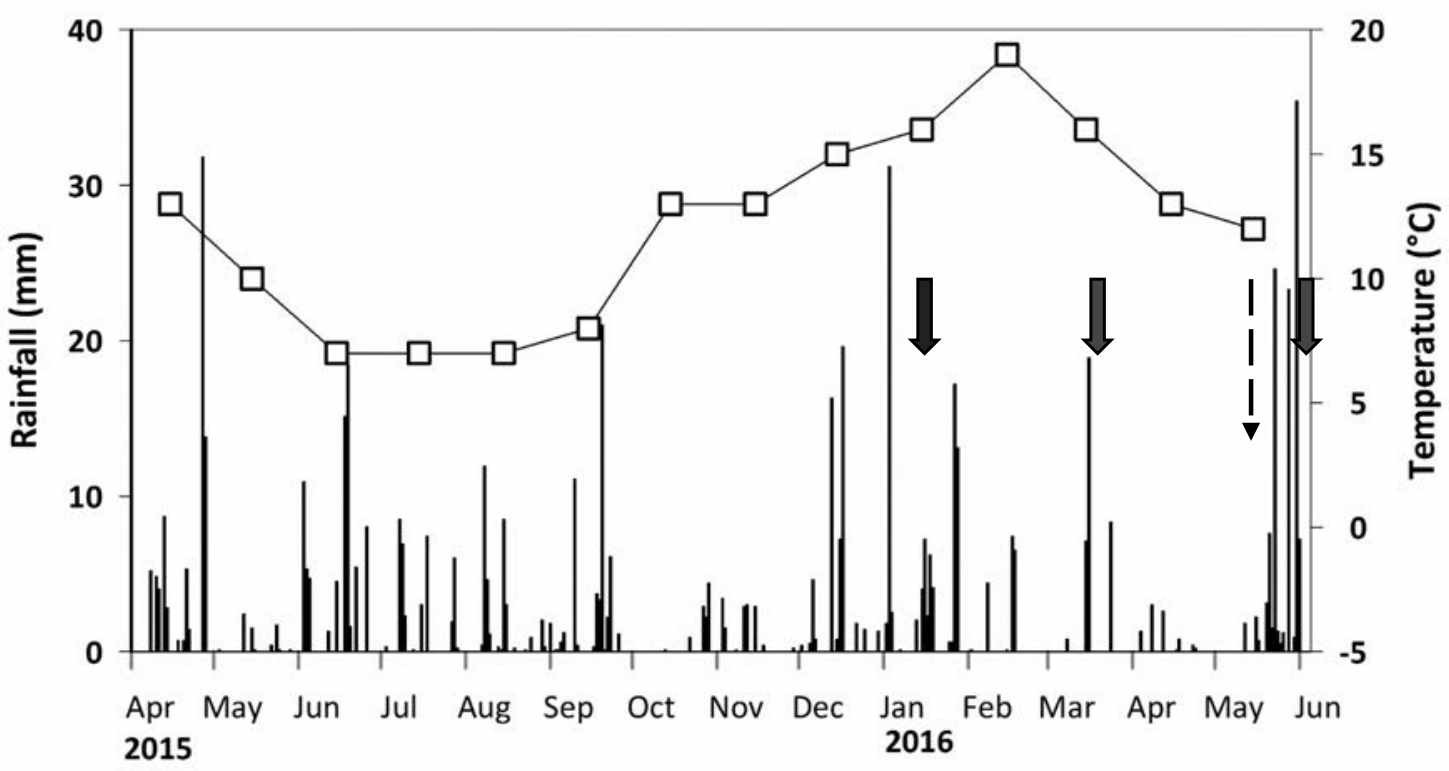

Months

Figure 1 Daily rainfall (mm, vertical bars) and mean monthly air temperature $\left({ }^{\circ} \mathrm{C}\right)$ from April 2015 to July 2016 at Broadfields weather station, Lincoln University. Solid arrows indicate emergence assessment dates (13th January, 17th March and 1st June 2016). The dashed arrow indicates when $20 \mathrm{~mm}$ of irrigation water was applied (11th May 2016).

plots were mechanically cut on 28th September and 17th November 2015 at $20 \mathrm{~mm}$ height using a ride-on Walker ${ }^{\circledR}$ mower. The herbage was removed to simulate grazing. Plots were then left to set seed and dry out from late November.

Long-term annual average rainfall for the study area is $630 \mathrm{~mm}$ and the total accumulated rainfall during the experiment (April 2015 to June 2016) was $629 \mathrm{~mm}$ (Figure 1). Annual Penman potential evapotranspiration is $1095 \mathrm{~mm}$ and usually exceeds rainfall from September to April, with a long-term potential soil moisture deficit of $500 \mathrm{~mm}$ (NIWA 2017). Potential evapotranspiration exceeded rainfall from October to December 2015 (310 $\mathrm{mm})$ and in early-February and April $2016(213 \mathrm{~mm})$. During the experiment the mean air temperature was $12^{\circ} \mathrm{C}$.

To estimate seed yield $(\mathrm{kg} / \mathrm{ha})$ subterranean clover burrs were sampled on 12th January 2016 with a metal corer (2 cores/plot, each $120 \mathrm{~mm}$ diameter) to $25 \mathrm{~mm}$ depth. Burrs and seeds were harvested from aboveand below-ground and then processed manually. The number of burrs, seeds and the seed weight $(\mathrm{mg})$ were recorded to estimate the percentage of burr burial and seed number $/ \mathrm{m}^{2}$.

Summer rain $(\sim 120 \mathrm{~mm})$ fell from mid-December 2015 to early-January 2016 (Figure 1) and caused the first seed emergence (first "false strike") in some cultivars. The number of seedlings at cotyledon to the two trifoliate leaf stage was counted on 13th January in eight $10 \times 10 \mathrm{~cm}$ quadrats in each plot and added to the seed number (seeds $/ \mathrm{m}^{2}$ ) to get the total seed density and seed yield values. Each plot was visually assessed for seedling mergence at four random points using a scale from 0-5. Emergence ratings were calibrated against seedling counts. Based on the January counts, the visual scale was adjusted to the range from 0 (no seedlings) to 5 (> 1500 seedlings $\left./ \mathrm{m}^{2}\right)$. The mean values (Table 1) were then used to create a simplified linear function (seedlings $/ \mathrm{m}^{2}=316 \mathrm{x}-64, \mathrm{R}^{2}=0.97$, where $\mathrm{x}$ corresponds to the visual score value) to estimate subsequent seedling populations (Teixeira et al. 2017).

On 22nd January 2016, all plots were mown (50 $\mathrm{mm}$ height) to remove tall broadleaf (mainly Rumex obtusifolius, Stellaria media, Taraxacum officinale, Chenopodium album, Polygonum aviculare and Achillea millefolium) and grasses (Lolium multiflorum and Phalaris aquatica) weeds. Broadleaf weeds were controlled with imazethapyr applied at a rate of 72 $\mathrm{g}$ a.i./ha $\left(300 \mathrm{ml} / \mathrm{ha}\right.$ Spinnaker $\left.{ }^{\circledR}\right)$ on $21 \mathrm{st}$ February. The emerged seedlings died (first "false strike") due to moisture deficit in late-February (Figure 1). New seedlings that had emerged were scored on 17th March 2016 (second "false strike") after accumulated rainfall of $90 \mathrm{~mm}$ (from 14th January to 17th of March). All weeds and subterranean clover were removed with glufosinate-ammonium herbicide (1000 g a.i./ha, 5L/ ha Buster $($ ) to assess a third emergence. The herbicide was applied on the 23rd March 2016. This created bare 
ground. A dry period in April (Figure 1) meant the area was irrigated on 11th May $(\sim 20 \mathrm{~mm})$ to encourage a third period of seedling emergence during the last 2 weeks of May. The third emergence was quantified on the 1 st June 2016.

The cumulative number of seedlings (seedlings/ $\mathrm{m}^{2}$ ) was subtracted from the total number of seeds produced $/ \mathrm{m}^{2}$ to calculate the number of seeds remaining ungerminated in the soil seedbank after the three emergence events. The percentage of seedlings lost was reported as seed losses over time (Equation 1).

Percentage of seed loss $(\%)=100 \times \frac{a}{b}$

Where, ' $a$ ' is the cumulative number of emerged seedlings $/ \mathrm{m}^{2}$ and ' $b$ ' is the total number of seeds $/ \mathrm{m}^{2}$. It was assumed that the percentage of seed loss was only due to emergence as seed losses due to insect or diseases were not quantified in this study (Simpson et al. 2001). The measured data were plotted against the burr burial score values (0-10) of Nichols et al. (2013) and a positive correlation $r=0.90$ ) was found. Results were analysed using one-way analysis of variance (ANOVA) using R software with Tukey's Honest Significance Test (THSD, $\alpha=0.05$ ). Minimum significant differences (MSD) are reported.

\section{Results}

There were differences $(\mathrm{P}<0.05)$ among cultivars in the percentage of buried burrs (Table 2). 'Antas' (brachycalycinum) had the lowest percentage of burr burial (40\%) in contrast to 'Coolamon' and 'Narrikup' (subterraneum, $>70 \%$ ).

The number of burrs $/ \mathrm{m}^{2}$ was almost $40 \%$ higher (P $=0.04$ ) for 'Mount Barker' than the other cultivars. The number of seeds in each burr was also affected $(\mathrm{P}<0.001)$ by cultivar.

There was a positive correlation $(r=0.80)$ between individual seed weights of harvested seed and initial sown seed weights (Figure 2). The individual seed weight $(\mathrm{mg})$ measured was also correlated $(\mathrm{r}=0.90)$

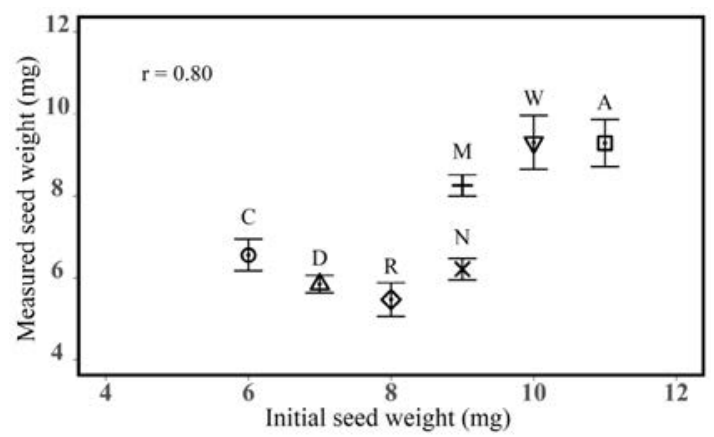

Figure 2 Mean measured seed weight $(\mathrm{mg})$ against the initial seed weight (mg) for subterranean clover cultivars 'Antas' $(\square)$, 'Coolamon' (O), 'Denmark' $(\triangle)$, 'Mount Barker' (+), 'Narrikup' (x), 'Rosabrook' $(\diamond)$ and 'Woogenellup' $(\nabla)$. Bars represent the mean standard error, $r=0.8$.

Table 1 A simplified scale to assist emergence estimates of subterranean clover seedlings used at the Field Research Centre, Lincoln University, New Zealand.

\begin{tabular}{lllllll}
\hline Score & $\mathbf{0}$ & $\mathbf{1}$ & $\mathbf{2}$ & $\mathbf{3}$ & $\mathbf{4}$ & $\mathbf{5}$ \\
\hline Number of seedlings $/ \mathrm{m}^{2}$ & 0 & 250 & 570 & 890 & 1200 & 1520 \\
\hline
\end{tabular}

Table 2 Mean burr burial (\%), number of burrs $/ \mathrm{m}^{2}$, number of seeds $/ \mathrm{burr}$, number of seeds $/ \mathrm{m}^{2}$ and seed yield (kg/ha) for seven subterranean clover cultivars after seed set in December 2016, at the Field Research Centre, Lincoln University, New Zealand.

\begin{tabular}{|c|c|c|c|c|c|}
\hline Cultivar & Burr burial (\%) & Burrs $/ \mathrm{m}^{2}$ & Seeds/burr & Seed number $/ \mathrm{m}^{2}$ & Seed yield (kg/ha) \\
\hline 'Antas' & $40.0_{b}$ & $2600_{b}$ & $3.5 \mathrm{a}$ & 8700 & 815 \\
\hline 'Coolamon' & $75.0_{a}$ & $3920_{a b}$ & $2.3_{c d}$ & 9270 & 570 \\
\hline 'Denmark' & $60.0_{\mathrm{ab}}$ & $3100_{a b}$ & $3.0_{a b}$ & 8845 & 515 \\
\hline 'Mount Barker' & $48.0_{a b}$ & $5390_{a}$ & $2.1_{d}$ & 11500 & 970 \\
\hline 'Narrikup' & $72.0_{a}$ & $3410_{a b}$ & $2.8_{b c}$ & 8710 & 550 \\
\hline 'Rosabrook' & $69.0_{\mathrm{ab}}$ & $3125_{a b}$ & $2.2_{c d}$ & 5725 & 340 \\
\hline 'Woogenellup' & $63.0_{\mathrm{ab}}$ & $3590_{a b}$ & $3.0_{a b}$ & 11120 & 1050 \\
\hline Mean & 61.0 & 3590 & 2.7 & 9120 & 690 \\
\hline$P_{\text {value }}$ & 0.007 & 0.04 & $<0.001$ & 0.35 & 0.04 \\
\hline MSD & 29 & 2550 & 0.6 & 7960 & 725 \\
\hline
\end{tabular}




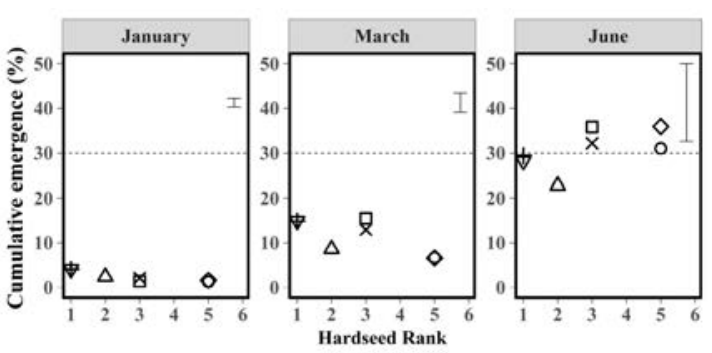

Figure 3 Mean cumulative percentage of emergence over time (January, March and June 2016) against hard seed rank (0-10, Nichols et al. 2013) for subterranean clover cultivars 'Antas' $(\square)$, 'Coolamon' (O), 'Denmark' ( $\triangle$ ), 'Mount Barker' (+), 'Narrikup' (x), 'Rosabrook' $(\diamond)$ and 'Woogenellup' $(\nabla)$. Bars are maximum standard error of the mean. Cultivar differences were: $\mathrm{P}=0.20, \mathrm{MSD}=$ 4.30 (January); $P=0.04, M S D=11.3$ (March); $P=$ $0.90, \mathrm{MSD}=39.0$. (June)

with previously reported seed weights for these cultivars (Nichols et al. 2013). At the first emergence in January, 'Mount Barker' and 'Woogenellup' had 4\% of total seeds emerged while 'Coolamon' and 'Rosabrook' had fewer than $2 \%$ (Figure 3).

By March, 'Coolamon', 'Denmark' and 'Rosabrook' had $<9 \%$ of seed emerged. In June, the total cumulative percentage of seed emerged after three emergence events was $31 \%$. Table 3 shows the actual values of seedlings $/ \mathrm{m}^{2}$ and emergence scores for each cultivar. The proportion of ungerminated seeds in January and March 2016 was positively correlated $(r=0.80$ and $r=$ 0.70 , respectively) with the Australian hardseededness rankings. In June, the seedling populations for all cultivars were greater than $1000 / \mathrm{m}^{2}$. The correlation

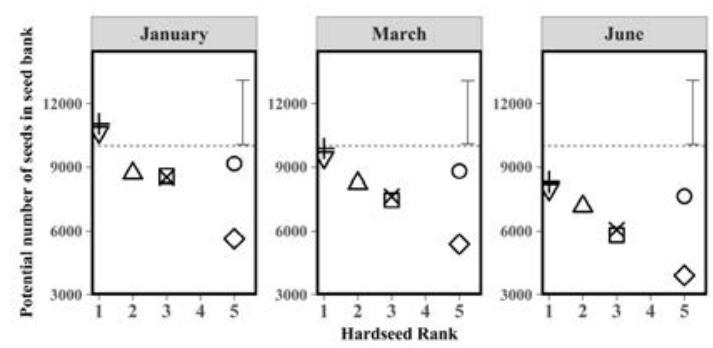

Figure 4 Mean estimated potential number of seeds (seeds $/ \mathrm{m}^{2}$ ) in seed bank against hard seed rank (0-10, Nichols et al. 2013) for subterranean clovers 'Antas' $(\square)$, 'Coolamon' (O), 'Denmark' $(\triangle)$ 'Mount Barker' (+), 'Narrikup' (x), 'Rosabrook' $(\diamond)$ and 'Woogenellup' $(\nabla)$. Bars are maximum standard error of the mean. Cultivar differences were: $P=0.40, M S D=7824$ (January); $P=0.59$, MSD $=7862$ (March); $P=0.57, M S D=7986$ (June).

with hardseededness rankings was $r=0.60$ and about $70 \%$ of the total number of seeds remained in the soil (Figure 3). These values corresponded to $\sim 8000$ seeds of 'Woogenellup' and 'Mount Barker' (Figure 4).

\section{Discussion}

The lenient cut regime (mechanical mowing in lateSeptember and mid-November) aimed at maximising seed set, was as recommended for first year subterranean clover sowing (Smetham \& Dear 2003). This ensured that 'Mount Barker' and 'Woogenellup' produced $>950$ $\mathrm{kg} / \mathrm{ha}$ and all other cultivars had seed yield above 260 $\mathrm{kg} / \mathrm{ha}$, the value considered the minimum for successful persistence (Smetham 2003). Individual cultivar yields ranged from $340-1000 \mathrm{~kg} / \mathrm{ha}$. The number of burrs $/ \mathrm{m}^{2}$

Table 3 Visual scores and seedling number $/ \mathrm{m}^{2}$ for seven subterranean clover cultivars measured in January, March and June 2016 at the Field Research Centre, Lincoln University, New Zealand.

\begin{tabular}{|c|c|c|c|c|c|c|}
\hline \multirow[b]{2}{*}{ Cultivar } & \multicolumn{2}{|c|}{ January } & \multicolumn{2}{|c|}{ March } & \multicolumn{2}{|c|}{ June } \\
\hline & Score & Seedlings $/ \mathrm{m}^{2}$ & Score & Seedlings $/ \mathrm{m}^{2}$ & Score & Seedlings $/ \mathrm{m}^{2}$ \\
\hline 'Antas' & 0.5 & 110 & $4.0_{\mathrm{a}}$ & $1120 \mathrm{a}$ & 5.0 & 1650 \\
\hline 'Coolamon' & 0.5 & 110 & $1.3_{c}$ & $347_{c}$ & 3.5 & 1150 \\
\hline 'Denmark' & 0.8 & 150 & $2.0_{b c}$ & $450_{b c}$ & 3.3 & 1070 \\
\hline 'Mount Barker' & 1.8 & 460 & $4.0_{a}$ & $1160_{a}$ & 4.8 & 1570 \\
\hline 'Narrikup' & 0.8 & 190 & $3.3_{a b}$ & $884_{a b}$ & 4.8 & 1570 \\
\hline 'Rosabrook' & 0.3 & 80 & $1.0_{c}$ & $252_{c}$ & 4.5 & 1480 \\
\hline 'Woogenellup' & 1.8 & 470 & $4.5 \mathrm{a}$ & $1200 \mathrm{a}$ & 4.5 & 1480 \\
\hline Mean & 1.0 & 226 & 3.0 & 773 & 4.0 & 1420 \\
\hline $\mathrm{P}$ & 0.07 & 0.05 & $<0.001$ & $<0.001$ & 0.09 & 0.08 \\
\hline MSD & 1.9 & 483 & 1.7 & 504 & 2.0 & 687 \\
\hline
\end{tabular}

Note: Numbers with a letter subscript in common are not significantly different $(a=0.05$, THSD). 
and individual seed weight were the main components that determined seed yield. These results demonstrated the high potential seed yield of all seven subterranean clover cultivars. The cumulative percentage of seed loss due to emergence in January and March was $\leq 15 \%$, meaning that despite two "false strike" events, $~ 85 \%$ of the seeds potentially remained in the seed bank. After the summer rains, 'Mount Barker' and 'Woogenellup' (hardseed score $=1$ ) had the greatest seedling emergence. With the summer rains in December and January, 'Woogenellup' and 'Mount Barker' had 4\% of seeds emerged. The seedlings that emerged with the second strike in March would be expected to survive at this location in most years. However, they were sprayed and were unlikely to have survived the 2016 autumn which was one of the warmest on record with $<60 \%$ of the long-term average rainfall (NIWA 2017). Had more frequent follow-up rain kept them alive, the early establishing cultivars would have had an advantage in canopy development and pasture growth in a favourable autumn (Moot et al. 2003; Teixeira et al. 2017). 'Rosabrook' and 'Coolamon' had delayed emergence which indicates these cultivars, with hardseed ranks above 4, may not be as suitable for dryland pasture systems in New Zealand as cultivars with lower ratings.

\section{Conclusions}

- "False strike" losses did not exceed $15 \%$ of the total seeds produced, with 'Woogenellup' and 'Mount Barker' having the highest seedling losses due to early summer rains

- The Australian cultivar rankings were reliable under Lincoln, Canterbury, conditions

- Cultivars produced sufficient seed (340 -1050 kg/ha) to establish satisfactory populations in their second year despite two episodes of "false strike".

\section{ACKNOWLEDGEMENTS}

The authors acknowledge the Ministry of Primary Industry (Sustainable Farming Fund, Project 408090), Beef + Lamb NZ, Seed Force Ltd, Luisetti Seeds Ltd, Mr Roland Stead for funding assistance. The Lincoln University, Field Research Centre and the Dryland Pasture team provided technical support.

\section{REFERENCES}

Brown, H.E.; Moot, D.J.; Lucas, R.J.; Smith, M. 2006. Sub clover, cocksfoot and lucerne combine to improve dryland stock production. Proceedings of the New Zealand Grassland Association 68: 109-115.

Dear, B.S.; Cregan, P.D.; Murray, G.M. 1993. Comparison of the performance of subterranean clover cultivars in southern NSW: 1. Persistence, productivity, and seed yields. Australian Journal of Experimental Agriculture 33: 581-590.
Dodd, M.; Sheath, G.; Richardson, S. 1995. Development of subterranean clover (Trifolium subterraneum L.) genotypes for New Zealand pastures 2. Wairakei persistence evaluation. New Zealand Journal of Agricultural Research 38: 49-56.

Hewitt, A.E. 2010. New Zealand soil classification. 4th Ed. Lincoln, New Zealand: Manaaki Whenua Press, Landcare Research.

Hudson, A.R.; Ayre, D.J.; Ooi, M.K.J. 2015. Physical dormancy in a changing climate. Seed Science Research 25: 66-81.

Monk, S.; Moot, D.J.; Belgrave, B.; Rolston, M.P.; Caradus, J.R. 2016. Availability of seed for hill country adapted forage legumes. Hill Country Symposium. Grassland Research and Practice Series 16: 257-267.

Moot, D.J.; Black, A.D.; Scott, W.R.; Richardon, J. 2003. Leaf development and dry matter production of subterranean clover cultivars in relation to autumn sward management. Legumes for Dryland Pastures. Grassland Research and Practice Series 11: 193200.

Nichols, P.G.H.; Foster, K.J.; Piano, E.; Pecetti, L.; Kaur, P.; Ghamkhar, K.; Collins, W. 2013. Genetic improvement of subterranean clover (Trifolium subterraneum L.). 1. Germplasm, traits and future prospects. Crop and Pasture Science 64: 312-346.

Nicotra, A.B.; Atkin, O.K.; Bonser, S.P.; Davidson, A.M.; Finnegan, E.J.; Mathesius, U.; Poot, P.; Purugganan, M.D.; Richards, C.L.; Valladares, F.; van Kleunen, M. 2010. Plant phenotypic plasticity in a changing climate. Trends in Plant Science 15: 684-692.

NIWA. 2017. New Zealand National Institute of Water and Atmosphere Research. Accessed: 20th July 2016. https://www.niwa.co.nz.

Norman, H.C.; Smith, F.P.; Nichols, P.G.H.; Si, P.; Galwey, N.W. 2006. Variation in seed softening patterns and impact of seed production environment on hardseededness in early-maturing genotypes of subterranean clover. Australian Journal of Agricultural Research 57: 65-74.

Smetham, M.L. 2003. A review of subterranean clover (Trifolium subterraneum L.): its ecology and use as a pasture legume in Australasia. Advances in Agronomy 79: 303-350.

Smetham, M.L.; Dear, B.S. 2003. The effect of continuous grazing on the seed production of subterranean clover (Trifolium subterraneum). Legumes for Dryland Pastures. Grassland Research and Practice Series 11: 155-160.

Simpson, R.J.; Richardson, A.E.; Riley, I.T.; McKay, A.C.; McKay, S.F.; Ballard, R.A.; Barbetti, M.J. 2011. Damage to roots of Trifolium subterraneum L. (subterranean clover), failure of seedlings to establish 
and the presence of root pathogens during autumnwinter. Grass and Forage Science 66: 585-605.

Taylor, G.B. 2005. Hardseededness in Mediterranean annual pasture legumes in Australia: A review. Australian Journal of Agricultural Research 56: 645661.
Teixeira, C.; Lucas, R.J.; Lewis, T.; Moot, D.J. 2017. From establishment to re-establishment: a field evaluation of sub clover cultivars. pp. 3-6. In: Proceedings of the $18^{\text {th }}$ Australian Society of Agronomy Conference, Ballarat, Australia. 